um espaço onde o Estado investiu para construir novas gerações e com o objetivo de definir novos modelos de maternidade.

Contudo, elementos ligados à regulação social e a preocupação com as práticas de saúde e relações de gênero referidas a sexualidade poderiam ser agregados à análise de modo a fazer perceber que as intervenções sobre a população também significaram intervenções sobre corpos e compromissos com a modernização dos comportamentos relativos à autonomia e a liberdade no campo dos direitos sexuais e reprodutivos.

Août 2007, Marlene Tamanini

\title{
André Freire, Esquerda e Direita na Política Europeia : Portugal, Espanha, e Grécia em Perspectiva Comparada, Lisbon, Imprensa de Ciências Sociais, 2006, 368 p., ISBN : 972-671-171-1.
}

Andre Freire has produced an exhaustive study of ideological orientations in the relatively new democracies of southern Europe - Portugal, Spain and Greece. The primary objective of the book is to ascertain how ideological and party identities in these new democracies compare with those in the old democracies of Western Europe such as Belgium, France, Great Britain, Germany, and Italy and the degree to which divisions along a left-right dimension continue to define political values across Europe.

Based on the author's doctoral thesis in political sociology at the Instituto de Ciências Sociais at the University of Lisbon, the book methodically blends the extensive theoretical literature on ideological and party identification with a rigorous use of comparative method to explore the multiple dimensions of political identity across Europe. Although the author is Portuguese, he follows in the tradition of much Anglo-American work in comparative politics by relying extensively on surveys of party affiliation, ideological positions, voter characteristics, beliefs, values, and preferences. Particularly for beginning graduate students, the book serves as an excellent example of how the comparative method should be used. The approach is systematic; it is theoretically driven and empirically sustained by a wealth of quantitative and qualitative data.

Like many dissertations that become books, however, the book's main contribution tends to get buried in the extensive efforts to review the literature and justify the approach. The book could have been pruned considerably to express more clearly its main arguments which are both compelling and important for scholars concerned with political affiliations and values in Europe. First, Freire claims that countries in southern Europe that became democratic in the late 1970s such as Greece, Spain, and Portugal displayed weaker partisan affiliations and ideological identities along a left-right dimension in the 1970s and 1980s than more established democracies in Europe. The main reason for this was that the authoritarian past in these three countries either interrupted (in the case of Greece) or thwarted (in the cases of Portugal and Spain) the growth of those ideological divisions and left-right orientations typically found in Europe's older democracies. In the absence of parties and other forms of political mobilization to shape voters' preferences, 
citizens in these countries only weakly adhered to ideological positions along a left-right dimension.

Given their histories, such findings might be expected but Freire's second claim is that since these countries in southern Europe became democratic in the late 1970s, ideological identities have been growing. Indeed, contrary to the « end of ideology » arguments made by some scholars following the conclusion of the Cold War, Freire finds that all across Europe, ideological identities along a left-right dimension have either stabilized or increased. Especially among younger voters in the newer democracies, the study finds that ideological orientations and preferences are beginning to mirror the divisions that are found in the older democracies. Whatever fluctuations have occurred in voters' ideological alignments have been short term; long term decline in alignments appear to have affected only two out of eleven cases analyzed and both of the countries are older democracies. This is an important finding because it suggests that in spite of globalization, the growth of the European Union, and major policy reforms such as the streamlining of the welfare state, voters can still distinguish between core right and leftwing values. Moreover, they consistently adhere to positions that are typically associated with the right (such as the right to life) or the left (such as the rights of workers).

Paradoxically, while ideological alignments have either stabilized or grown, the same has not been true for political party affiliations. With the exception of Spain and Holland where party identity has stabilized, party dealignment has been marked across Europe regardless of the age or quality of democracy. This creates a dilemma for European democracies since Freire claims that parties are a key mechanism for educating the electorate about their political and policy preferences. Building on the work of other scholars in the field such as Ronald Inglehart, Richard Gunther, Russel Dalton, and Martin Wattenberg, Freire notes that the greater the ideological distance between the two major parties in a country, the more ideologically sophisticated voters are. As European parties have altered their party platforms to attract new voters or to address changed circumstances in their countries, these distances have now diminished, with the result that voters'party affiliations have weakened.

Given how salient parties are to the development of ideological orientations, Freire could have spent more time addressing the potential impact of party dealignment on ideological orientations and democracy in general. In a recent article, for example, Peter Mair has argued that the failure of parties to engage with voters in a meaningful way has led to a decline in turnout by voters across Europe, an increase in voter volatility, and a decrease in party membership. While the rate of decline in turnout has been slow, in 11 out of the 15 countries Mair examined, there is a definite pattern of increased abstention rates over the course of the 1990s. Partisan attachments have declined even more dramatically. Except for Greece and Spain, party membership from France to Portugal has declined since the $1980 \mathrm{~s}^{1}$.

What are we to make then of the contradiction posed by the increase or maintenance of ideological orientation at the same time that partisan affiliations

${ }^{1}$ P. MAIR, «Ruling the Void? The Hollowing of Western Democracy », New Left Review, 42, November-December 2006: 25-51. 
are declining? What will the likely impact be? Mair's work concludes that the decline in voter turnout and the drop in party membership raise serious doubts about the capacity of European democracies to be truly representative of the wishes of voters. Other than to reiterate that parties and party elites are central to the formation of ideological identities, Freire does not address the question directly. Yet his findings point us in a number of different directions that future work might investigate.

On the one hand, if parties continue to go after the center then we can expect a weakening of the ideological orientations that Freire has so painstakingly traced. Such a scenario might increase policy stability within European democracies, but it will mean that the electorate will lose the ability to distinguish between leftist orientations that promote the welfare state, the rights of workers, a just society, equality, etc. and conservative positions that value the right to life, the role of religion, individual responsibility, or private property. On the other hand, if it is the case that ideological orientations along a left-right continuum are growing or stable, but that voters are increasingly frustrated with parties then citizens may seek out alternative modes of expressing their dissatisfaction with governments across Europe. Both France and Britain have experienced already widespread protests by young people around the issues of jobs in the former case and the Iraq war in the latter, because existing political parties and ruling elites were unresponsive to their concerns. If this scenario prevails, we can expect an increase in other forms of civic engagement beyond voting and party identification such as participation in new social movements, transnational advocacy networks, or more extremist organizations on both the left and the right. These forms of civic engagement may re-invigorate European democracy or they may disable it. These are pressing issues that demand the attention of scholars. The strength of André Freire's book is that it provides a solid empirical foundation on which to build such studies.

June 2007, M. Anne Pitcher

\section{Manuela Marujo, Aida Baptista \& Rosana Barbosa (eds), The voice and choice of Portuguese immigrant women/A vez e a voz da mulher imigrante portuguesa, Toronto, University of Toronto, 2005, 208 p., ISBN : 0-9690025-1-3.}

This bilingual volume contains the proceedings of a conference held at the University of Toronto in September 2003 on the role of the Portuguese immigrant woman in different countries and continents where she has built a new life away from the infrastructure, family and friends of her original homeland. The various articles are contributions from academics, writers and artists, not only from Canada but also from Australia, Brazil, China, the U.K., mainland Portugal and the Azores, and the U.S.

In the opening pages, Maria de Jesus Soares highlights the 'gender gap'in the opportunities available to immigrant women and men, and José Bouza Serrano comments on the key part played by women in the transmission of cultural values at home and abroad. The main body of the book is organized into six thematic areas. Each one develops a number of related topics. 